\title{
Changes in red cell deformability and other haemorrheological variables after myocardial infarction
}

\author{
A J DODDS, $M$ J BOYD, JUDITH ALLEN, E D BENNETT, P T FLUTE, \\ J A DORMANDY
}

From St George's Hospital Medical School, London

SUMMARY Haemorrheological variables were studied in 43 patients after acute myocardial infarction. Red cell deformability, by a filtration method, was significantly lower within 12 hours of infarction than subsequently. This drop was greater in the presence of haemodynamic complications. Blood viscosity, particularly when adjusted to a standard haematocrit, rose in the week after infarction, as did plasma viscosity and plasma fibrinogen. Haematocrit, however, fell over this period. These changes could increase myocardial ischaemia and lead to extension of the area of infarction.

Myocardial infarction is an important cause of death in Western communities. ${ }^{1}$ Though there is still disagreement on the pathogenesis of the vascular occlusion, current interest lies in limiting the ultimate size of the infarct by preventing extension into the surrounding area of marginal ischaemia. Changes in the physical flow properties of blood may have an important influence on blood flow and oxygen supply to ischaemic myocardium. ${ }^{2}$ The purpose of this study was to examine the changes in red cell deformability and other haemorrheological variables after acute myocardial infarction.

\section{Patients and methods}

Forty-three patients with myocardial infarction ( 35 men, eight women; age range 33 to 76 years; mean Received for publication 9 May 1980 age 58.6 years) admitted consecutively to the intensive care unit were studied. Requirements for a diagnosis of myocardial infarction were two or more of the following: (a) typical history; (b) an increase in the serum aspartate transaminase or serum hydroxybutyrate dehydrogenase concentration to more than twice the upper limit of normal within three days of admission; and (c) characteristic evolutionary electrocardiographic abnormalities.

Samples of blood were drawn from an antecubital vein using a $21 \mathrm{G}$ needle without cuff occlusion: $20 \mathrm{ml}$ was anticoagulated with solid lithium heparin $(12.5$ units $/ \mathrm{ml})$ for rheological studies and $5 \mathrm{ml}$ with $0.5 \mathrm{ml}$ of 3.8 per cent trisodium citrate solution for plasma fibrinogen estimation. Collections were made one, three, five, and 10 days after the presumed infarction indicated by the history. Samples were not collected at weekends,

Table Haemorrheological variables after myocardial infarction (mean $\pm S E M$ )

\begin{tabular}{|c|c|c|c|c|c|}
\hline & Day 0 & Day 1 & Day 3 & Day 5 & Day 10 \\
\hline $\begin{array}{l}\text { Blood viscosity } 0.77 / \mathrm{s}(\mathrm{mPa} / \mathrm{s}) \\
\text { Blood viscosity }(\mathrm{C}) 0.77 / \mathrm{s}(\mathrm{mPa} / \mathrm{s}) \\
\text { Blood viscosity } 2 \cdot 62 / \mathrm{s}(\mathrm{mPa} / \mathrm{s}) \\
\text { Blood viscosity }(\mathrm{C}) 2 \cdot 62 / \mathrm{s}(\mathrm{mPa} / \mathrm{s}) \\
\text { Blood viscosity } 91 / \mathrm{s}(\mathrm{mPa} / \mathrm{s}) \\
\text { Blood viscosity }(\mathrm{C}) 91 / \mathrm{s}(\mathrm{mPa} / \mathrm{s}) \\
\text { Plasma viscosity }(\mathrm{mPa} / \mathrm{s}) \\
\text { Haematocrit }(\%) \\
\text { Plasma fibrinogen }(\mathrm{g} / \mathrm{l}) \\
\text { Deformability index } \\
\text { n }\end{array}$ & $\begin{aligned} 26 \cdot 7 & \pm 2 \cdot 1 \\
26 \cdot 3 & \pm 1 \cdot 5 \\
15 \cdot 3 & \pm 1 \cdot 1 \\
14.5 & \pm 0.7 \\
4 \cdot 8 & \pm 0 \cdot 2 \\
4 \cdot 7 & \pm 0 \cdot 1 \\
1 \cdot 41 & \pm 0.03 \\
45 \cdot 0 & \pm 1 \cdot 1 \\
4 \cdot 3 & \pm 0.3 \\
0.22 & \pm 0.04 \\
17 & \end{aligned}$ & $\begin{aligned} 29 \cdot 6 & \pm 1.5 \\
30 \cdot 1 & \pm 1.0^{\star} \\
16.8 & \pm 0.6 \\
16.7 & \pm 0.4^{\star \star \star} \\
4.8 & \pm 0.1 \\
4.9 & \pm 0.1 \\
1.45 & \pm 0.02 \\
44.0 & \pm 0.9 \\
4.6 & \pm 0.2 \\
0.49 & \pm 0.05 \ddagger \\
33 & \end{aligned}$ & $\begin{aligned} 31.7 & \pm 1.4 \\
33.9 & \pm 0.9 \ddagger \\
16.6 & \pm 0.7 \\
17.3 & \pm 0.4^{\star \star \star} \\
5.0 & \pm 0.1 \\
5.1 & \pm 0.1^{\star} \\
1.52 & \pm 0.02 \star \star \star \\
43.1 & \pm 0.7 \\
6.3 & \pm 0.2 \ddagger \\
0.55 & \pm 0.03 \\
39 & \end{aligned}$ & $\begin{aligned} & 29.6 \pm 1.4 \\
& 33.9 \pm 1 \cdot 2 \ddagger \\
& 16.6 \pm 0.6 \\
& 18.0 \pm 0.6 \ddagger \\
& 4.8 \pm 0.2 \\
& 5 \cdot 1 \pm 0.1^{\star} \\
& 1.54 \pm 0.02 \ddagger \\
& 41 \cdot 7 \pm 0.6^{\star \star} \\
& 6.9 \pm 0.3 \ddagger \\
& 0.56 \pm 0.03 \ddagger \\
& 38\end{aligned}$ & $\begin{aligned} & 28 \cdot 6 \pm 1 \cdot 0 \\
& 32 \cdot 8 \pm 1 \cdot 0 \star \star \star \\
& 16 \cdot 3 \pm 0 \cdot 7 \\
& 17 \cdot 8 \pm 0.5 \ddagger \\
& 4 \cdot 7 \pm 0 \cdot 1 \\
& 5 \cdot 1 \pm 0 \cdot 1^{\star} \\
& 1 \cdot 60 \pm 0.02 \ddagger \\
& 41 \cdot 3 \pm 0 \cdot 7^{\star \star} \\
& 6 \cdot 3 \pm 0.3 \ddagger \\
& 0.63 \pm 0.02 \ddagger \\
& 36\end{aligned}$ \\
\hline
\end{tabular}

(C) adjusted to a standard haematocrit (45\%).

$\star p<0.05 . \quad \star \star p<0.02 . \quad \star \star \star \star p<0.01 . \quad+p<0.005 . \quad \neq p<0.001$ when compared with day 0 . 
and some final samples were not collected because of death or discharge from hospital. Seventeen patients had an additional sample drawn within 12 hours of infarction (day 0 ).

Red cell deformability was assessed by a filtration method previously described ${ }^{3}$ in which a 5 per cent suspension of red cells in autologous prefiltered plasma was passed through individual $5 \mathrm{um}$ Nuclepore polycarbonate sieves (Nuclepore Corporation, Pleasanton, California, USA). The deformability index was defined as the fraction of $1 \mathrm{ml}$ of this suspension filtered in $60 \mathrm{~s}$.

Whole blood viscosity at shear rates of $0.77 / \mathrm{s}$, $2 \cdot 62 / \mathrm{s}$, and $91 / \mathrm{s}$ together with plasma viscosity were measured at $37 \mathrm{C}$ using a Contraves low shear 2 rheometer. ${ }^{4}$ The results were also adjusted to a standard haematocrit of 45 per cent. ${ }^{4}$ Plasma fibrinogen by a clot weight method, ${ }^{5}$ and microhaematocrit were also measured.

Student's t test (two-tailed) was used for statistical analysis.

\section{Results}

The results for the whole group are contained in the Table. Red cell deformability was lowest on day 0 , rising significantly by day 1 , with small increases thereafter $(p<0.001)$ (Fig. 1). The earliest deformability index determined (day 0 or 1 ) was lower in 11 patients with radiological alveolar or interstitial pulmonary oedema on admission $(0 \cdot 22$ 0.07 SEM) than in patients without oedema $(0.470 .05$ SEM) $(p<0.01)$ (Fig. 2). Five patients with cardiogenic shock (systolic blood pressure $<100 \mathrm{mmHg}$, cool peripheries, oliguria) had lower earliest deformability indices $(0.110 .04$ SEM $)$ than those without shock $(0.44 \div 0.05 \quad$ SEM $)$

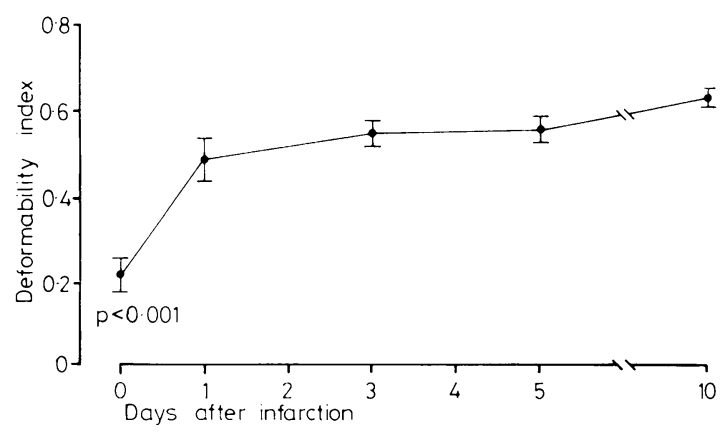

Fig. 1 Change in red cell deformability after myocardial infarction (mean SEM). The day 0 value is significantly different from the values on all other days.

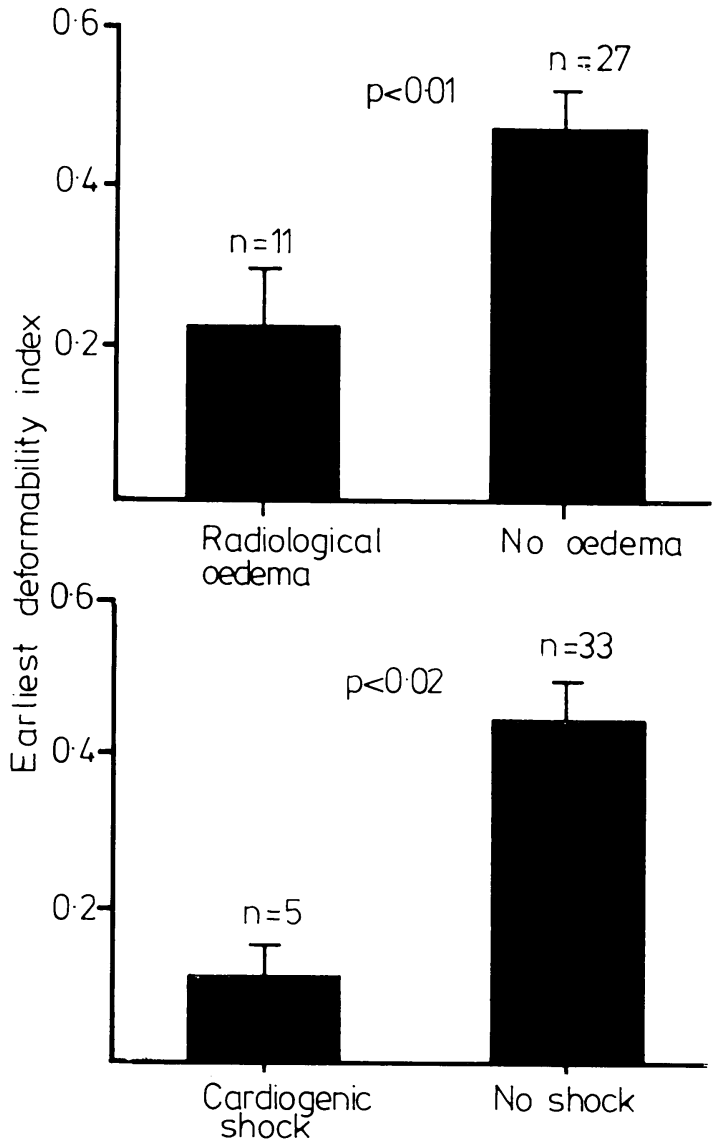

Fig. 2 Earliest deformability indices in those with radiological pulmonary oedema on admission compared with those without oedema and those with cardiogenic shock compared with those not shocked (mean SEM).

$(\mathrm{p}<0 \cdot 02)$. Three of those with shock died within two weeks of infarction (indices $0,0,0.22$ ).

Whole blood viscosity, when adjusted to a standard haematocrit, increased significantly by the third day at each of the three shear rates. The greatest increase occurred at the lowest shear rate, where there was a 29 per cent rise over the initial reading. Plasma fibrinogen and plasma viscosity also showed significant increases by the third day. Haematocrit, however, decreased, being 10 per cent lower on the fifth day. Whole blood viscosity without correction for haematocrit did not change at the highest shear rate and showed only insignificant rises at the other shear rates.

Patients sampled on day 0 did not appear to be a select group because they did not differ significantly from other patients in peak cardiac 
enzyme concentrations or in the haemorrheological values measured on the subsequent days.

\section{Discussion}

Myocardial ischaemia has been associated with abnormal blood rheology in a number of reports. ${ }^{6}$ ? After myocardial infarction, whole blood viscosity, plasma viscosity, and plasma fibrinogen have been shown to be raised. ${ }^{89}$ In previous reports red cell deformability has only been assessed by a viscometric method. ${ }^{9}$ We have chosen microfiltration which we believe to be a better model of the microcirculation. Further, we have used red cells resuspended in autologous plasma to include the influence of plasma proteins and other plasma factors on red cell deformability.

In this study we have confirmed previous observations on the changes in blood viscosity after myocardial infarction. A significant increase in whole blood viscosity at low shear rate was found when adjusted to a standard haematocrit. The rise in whole blood viscosity, however, at the low shear rate when not adjusted for haematocrit did not quite reach significance. The explanation appeared to be the opposing influences of a rise in plasma fibrinogen and a fall in haematocrit. A reduction in haematocrit will lead to a reduction in blood viscosity whereas a rise in plasma fibrinogen concentration will increase red cell aggregation, and thus increase blood viscosity measured at low shear rates. ${ }^{4}$ Increased blood viscosity could well alter blood flow and oxygen delivery to ischaemic myocardium. ${ }^{2}$ It is now established that an area of ischaemic tissue exists around a central area of infarction. ${ }^{10}$ Maintenance of blood flow to this region may be crucial in limiting the ultimate infarct size. As blood flow in the coronary circulation is predominantly diastolic, and thus over a relatively small pressure difference, even a small increase in blood viscosity at low shear rates could further reduce flow. ${ }^{211}$

The most striking observation in this study is the low red cell deformability, as indicated by the reduced proportion of red cells able to pass a $5 \mu \mathrm{m}$ filter, during the first 12 hours after myocardial infarction. This phenomenon was most pronounced in the presence of haemodynamic complications, particularly cardiogenic shock. Factors other than red cell deformability that might impair filtrability of red cells are unlikely to explain this finding. Buffy coat removal and plasma filtration before resuspension of cells avoid filter plugging by leucocytes. Use of a dilute red cell suspension minimises red cell interaction and resulting rouleaux or aggregates. Indeed, were the latter a major factor, the increased aggregability by day 3 , indicated by the rise in whole blood viscosity at the lowest shear rate after correction to a standard haematocrit, would have further impaired filtrability. In fact the filtration of red cells had returned to almost normal by the third day, supporting the concept that filtration changes primarily reflect changes in red cell deformability. In vivo, normal deformability allows red cells, whose greater diameter usually exceeds $7 \mu \mathrm{m}$, to pass through segments of capillaries as narrow as $3 \mu \mathrm{m}$ in diameter. ${ }^{12} \mathrm{~A}$ reduction in deformability could lead to impaired perfusion in the microcirculation and this may be particularly important in an area of myocardial ischaemia where acidosis would further impair red cell deformability. ${ }^{12}$

The changes we have described are most likely to be secondary and not related to the pathogenesis of the infarct. They could well aggravate the ischaemia in the myocardium, however, and lead to extension of the area of infarct. Treatment designed to prevent or reduce these effects may be an approach to explore in the immediate management of myocardial infarction.

We acknowledge the financial support of Bristol Myers Co Ltd. A J D is supported by Berk Pharmaceuticals and the Pathology Research Fund of St. George's Hospital.

\section{References}

1 World Health Organisation. World Health Statistics Annual. Vol. 1: Vital statistics and causes of death. Geneva: World Health Organisation, 1977.

2 Gordon RJ, Snyder GK, Tritel H, Taylor WJ. Potential significance of plasma viscosity and hematocrit variations in myocardial ischemia. $\mathrm{Am}$ Heart f 1974; 87: 175-82.

3 Dodds AJ, O'Reilly MJG, Yates CJP, Flute PT, Dormandy JA. Haemorrheological response to plasma exchange in Raynaud's phenomenon. $\mathrm{Br}$ Med $\mathrm{f}$ 1979; ii: $1186-7$.

4 Dormandy JA. Mechanical and engineering problems of blood viscosity. Biomed Eng 1974; 9: 284-303.

5 Ingram GIC. The determination of plasma fibrinogen by clot weight method. Biochem $\mathcal{F}$ 1952; 51 : 583-5.

6 Burch GE, DePasquale NP. Hematocrit, blood viscosity and myocardial infarction. Am f Med 1962; 32: 161-3.

7 Nicolaides AN, Bowers R, Horbourne T, Kidner PH, Besterman EM. Blood viscosity, red-cell flexibility, haematocrit, and plasma fibrinogen in patients with angina. Lancet 1977; ii: 943-5.

8 Fulton RM, Duckett K. Plasma-fibrinogen and thromboemboli after myocardial infarction. Lancet 1976; ii: $1161-4$.

9 Jan KM, Chien S, Bigger JT Jr. Observations on 
blood viscosity changes after acute myocardial infarction. Circulation 1975; 51: 1079-84.

10 Maroko PR, Braunwald E. Modification of myocardial infarction size after coronary occlusion. Ann Intern Med 1973; 79: 720-33.

11 Salisbury PF, Cross CE, Rieben PA. Acute ischemia of inner layers of ventricular wall. Am Heart $\mathcal{F} 1963$; 66: $650-6$.
12 Anonymous. Red cell deformability (leading article). Lancet 1978; ii: 1348-9.

Requests for reprints to Dr M J Boyd, St George's Hospital Medical School, London SW17 ORE. 